\title{
Impact of Effective Information Technology Governance on Audit Technology Performance in Ghana
}

\author{
Yusheng Kong $^{1} \quad$ Samuel Edwin Nelson ${ }^{2}$ \\ 1.School of Finance and Economics, Jiangsu University, Jiangsu Province, P.R. China \\ 2.School of Finance and Economics, Jiangsu University, Jiangsu Province, China
}

\begin{abstract}
The notion of Industry 4.0 significantly changed the way firms' operate and has influenced everyday life. The rapid digitalization and emergent trend of information technology (IT) transformation in firms and ample investment in IT by Ghanaian government stimulated the importance of IT-based risks and its associated controls. In addition, technology enabled the auditing and IT-related audit methods have significance when carrying out audit tasks. This study aims to investigate the effects of IT governess effectiveness on audit technology performance in the public sector of Ghana. This study used closed-ended to collect data. An online survey admitted to record 186 responses. The findings of the study stated that top management support, IT support services, and IT committee have a positive and statistically significant influence on audit technology performance. The proposed model of the study explained $65.1 \%$ variance in the audit technology performance. The study proposes that public sector companies must strengthen IT governance by developing an appropriate IT committee and IT support services for the auditors. Besides, firms should clearly elucidate their priorities and requirements associated with technology-based training in their IT policies, and action plans to improve the utilization of audit technology.

Keywords: Information technology governance, audit technology performance, IT support services, IT committee, top management support.
\end{abstract}

DOI: $10.7176 /$ RJFA/11-24-05

Publication date: December $31^{\text {st }} 2020$

\section{Introduction}

Information and communication technology (ICT) is constantly playing a key role in employment creation, increase in small and medium-sized enterprises performance, and networking sites enabling individuals and organizations to interact through innovation (Chege et al., 2020). Technology innovation is understood as a tool that provides a competitive advantage to the organization and played a key role in firm performance (Chege \& Wang, 2020; Sikandar Ali et al., 2020). The idea of industry 4.0 has significantly deviated the way firms operate and this revolution affected every facet of life. In earlier, Industry 1.0 focused on the betterment of manufacturing operations, Industry 2.0 on mass production utilizing electrical energy, Industry 3.0 on the automation of uniform job functions. The main purpose of the fourth industrial revolution is to improve automation and operational efficiency as well as effectiveness (Xu, 2020). In line with increasing attention towards the globalization and rapid digitization of work processes particularly involving both private and public sectors respectively, there are growing initiatives by developing countries like Ghana in ICT-based projects to escalate an efficient and effective service delivery. Therefore, the ICT-based investment has been increased in government and non-governmental institutions and has triggered largely the importance of ICT-related investment in public sector service delivery and the estimated rate of return from such investment is also a main concern largely among governmental institutions and citizens. Nonetheless, in most of the ICT-based projects being examined, the major concerns were system underutilization in terms of functionality. The audit evaluation on ICT-based projects resulted in interesting facts such as lack of knowledge and training, ambiguity in system specification, delay in execution of projects due to constant changes, and databases were not up-to-date due to lack of monitoring (World Bank, 2016).

Admittedly, each organization in the public sector relies on the IT department to conduct their operations, IT governance has gained significant attention in recent years (Joshi et al., 2018). Furthermore, IT governance also received ample attention from scholars, practitioners, given the fact that IT extends a firm's strategy and objectives into IT (Mikalef et al., 2020). (Mehdi et al., 2018) argued that IT governance enables the organization to set-up clear expectations, open communication, gain participation, establish accountability, and provide management oversight. Therefore, IT governance is critical for the firms; effective IT governance requires a set of mechanisms, such as IT organizational structure and committee that can stimulate actions consistent with the firm's mission. IT transformation can influence the existing governance system, leading to a decrease in the capacity, and ability of IT in a public sector firm, if this conversion ignores the assets and people devoted to the system (Telino et al., 2020). This governance is imperious to warrant the successful execution of service delivery to achieve organization goals, whereby the decision-making process and monitoring system are linked with the corporate goals and citizens prediction (Mukhtar \& Ali, 2011).

A highly advanced computerized accounting system had several implications for current audit activities and led to the need for new audit techniques to assess control to diminish new business risk (Tarek et al., 2017). The 
growing requirement of audit standards has emerged the necessity of technology-based audit approaches (KAHYAOGLU et al., 2020). Due to increasing digitalization in companies and their business auditors requires embracing analytics quickly. However, the advantage of IT-based audit methods being extensively recognized, some auditors are still lacking in performing technology-based audit tasks. Furthermore, prior studies evidenced the slow adoption of technology associated with audit (Bierstaker et al., 2014; Smidt et al., 2019), and authors also evidenced that auditors are not gaining sufficient progress in technology-related audit performance and technology-related competency (Christensen, 2016). Within the Ghana context, the Auditor General of Ghana has also shown huge concern over the under-employment of audit technology (Ibrahim et al., 2017; Shiraz Rahaman, 2009) and most of the auditors in the country are focusing on the traditional form of IT control instead of advanced.

However, multiple actions are taken to advance the adoption and use of technology among auditors irrespective of private and public, but IT use among auditors remain still slow. It pinpoints that the current strategies, policies, and action plans are not effectively supported the implementation of technology. The main determinants behind the IT-based project failure are associated with inadequate IT governance, insufficient management support, no clear direction regarding IT business performance, lack of IT support activities, and improper IT plans (Amid et al., 2012; Veerankutty et al., 2018). Consequently, this study aims to investigate the effect of governance mechanisms on the audit technology performance among Ghana public sector auditors.

\section{Literature review and hypotheses development}

\subsection{IT governance}

Firms with effective IT governance intensely developed a group of IT governance mechanisms that influence behavior in-line with the firm vision and mission, strategy and policy, norms, values, and culture. According to (Rau, 2004) IT effective governance occurred when the firm has a "set of mechanism" which includes process, structure, and communication. (Sirisomboonsuk et al., 2018) stated that it comprises of management participation, IT policies, well-disseminated strategies, IT structure, and well-defined performance factors. Also, top management support in the adoption of technology, and IT-related decision-making, the establishment of IT committee for handling IT-based issues, and the utilization of key performance factors related to IT have significantly assessed the effectiveness of IT governance (Alreemy et al., 2016; Ferguson et al., 2013).

\subsection{Audit technology performance}

Technology-based auditing is considered the most significant area in audit function, specifically in the use of audit technology (Christensen, 2016). The auditors necessitate incorporating " state of art" audit technology to improve the audit process (Sirisomboonsuk et al., 2018). The most frequently proposed audit technology often endorsed by practitioners and professionals and standards are Computer-Assisted-Audit-Tools. The most frequently used auditbased technology, specifically, during the technology-enabled auditing, are: "(1) test data, parallel simulation and integrated test facility assessing the internal logic of the financial application directly and to test a program is functioning as intended and correctly; (2) generalized audit software being used to access client electronic files, extract related data, and conduct substantive tests to examine the details of transaction and balances, and perform analytical reviews to identify unusual transactions; (3) system control audit review files (SCARF) and embedded audit modules being installed into the system to evaluate flows of transaction and identify exceptional transactions" (Veerankutty et al., 2018, p. 4).

\subsection{IT governance and audit technology performance.}

Agency theory is used to explain the phenomena, as existing research showed agency theory being largely employed in public sector accountability investigation (Ferguson et al., 2013) and is greatly associated with governance concerns such as monitoring mechanism (KAHYAOĞLU et al., 2020; Smidt et al., 2019). Effective implementation of IT governance mechanisms can lead a firm to use and manage the technology in business more efficiently compared to the firm in which IT governance is ineffective. It may enhance the administration of ITbased activities by promising technology is in-line with company objectives, IT outcomes being scrutinized effectively (Lunardi et al., 2017). Top management support is a significant factor in creating a supportive environment and allocating resources for the successful initiative (Ahmed, Li, Qalati, et al., 2020), adoption and use of technologies (Sirisomboonsuk et al., 2018) and is being an important factor in making decision-related to technology adoption in audit organization and small and medium-sized enterprises (Mahzan \& Lymer, 2014; Siew et al., 2020).

Furthermore, the studies highlighted that IT strategy as the "technology-based strategic policy" is providing direction and guidance on IT-based activities (Nfuka Edephonce \& Rusu, 2011) and IT steering committee as an encouraging and supporting mechanism for managing information system-related activities (Ferguson et al., 2013) are crucial mechanism for effective IT governance. Moreover, the IT support services also play a critical role in enabling the utilization of audit technology among public auditors (Miklos \& Romero, 2014). Therefore, firms should effectively govern the company's IT-based activities with accurate infrastructure in supporting technology 
utilization among auditors and recommended provision of IT support services intending to improve auditor's confidence in using audit technology (Bierstaker et al., 2014; Veerankutty et al., 2018). Thus, this study estimated that IT governance mechanism influence audit technology performance. Therefore, we hypothesize as following:

Hla: Top management support has a significant influence on audit technology performance.

H1b: IT support services have a significant influence on audit technology performance.

H1c: IT committee has a significant influence on audit technology performance.

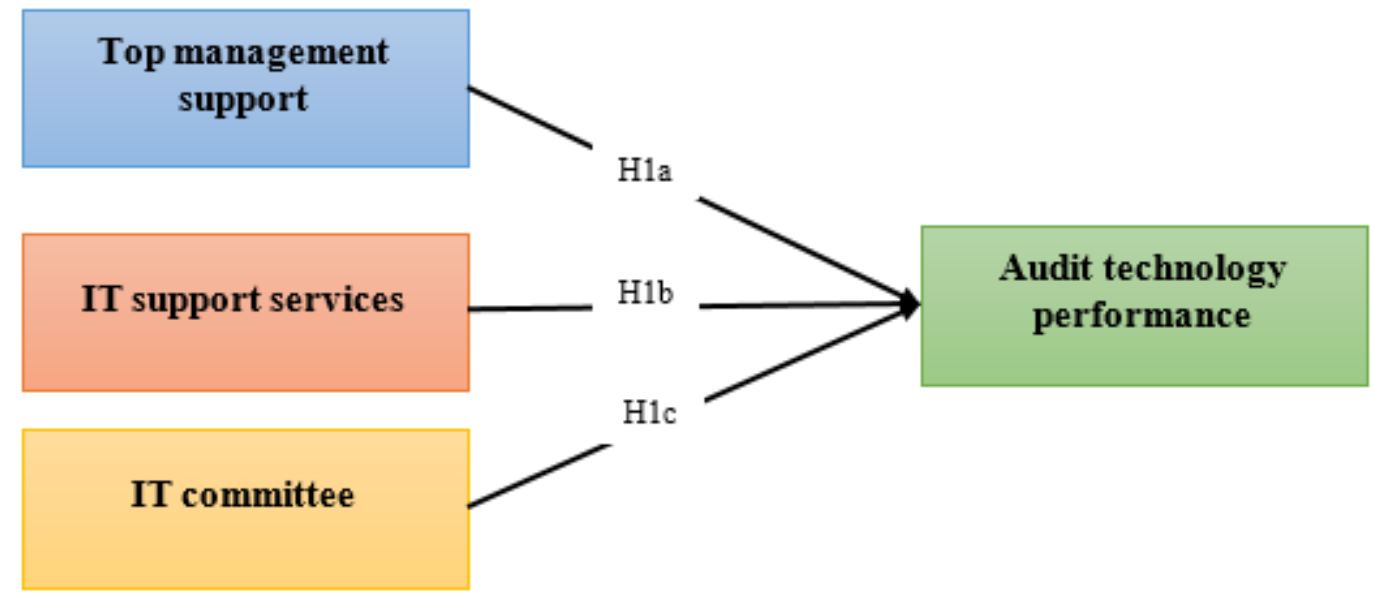

Figure 1. Proposed conceptual model

\section{Research methodology}

3.1 Sample size and data collection

The unit of this study includes the public sector auditor's working in different companies such as Ghana Audit Service, EAK \& Associates, Mazars Group, and others. Data of the study was collected by cluster sampling through segregating audit staff functions. After collecting email addresses from the companies, an online Google form was created to approach them. Grounded on the existing literature-related to online surveys particularly in public organizations, 20 to 30 percent were assumed to be reasonable (Saunders et al., 2009). In addition, online surveys considered a cost-effective and efficient mode nowadays due to the current pandemic COVID-19 (Sikandar Ali Qalati et al., 2020), and are largely used in upcoming research (Sikandar Ali Qalati et al., 2020). A multistage approach of data collection was encountered, whereby at first a total of 300 auditors contacted via email, every after two weeks a reminder was sent. Data collection was carried out for the three months from July 2020 to September 2020. Three months lag time was selected to reduce the bias (Tian et al., 2020). In total 186 valid responses were received with a response rate of $62.0 \%$.

\subsection{Data analytical tool}

Smart PLS 3.2.8 was used to evaluate the associations among the proposed variables by Partial Least Square Structural Equation Modeling (PLS-SEM). PLS-SEM is a widely used and acceptable technique that enables the concurrent analysis within latent variables and between measurement items (Hair Joseph et al., 2019; Sikander Ali Qalati et al., 2019; Qiang et al., 2019). Furthermore, these techniques believed to be the most appropriate data analytical approach as this research intends to examine the predictive relationship among dependent and independent constructs (Ahmed, Li, Qalati, et al., 2020)

\subsection{Measurement scale}

This study used three independents and one dependent variable. All the constructs measured using a 5-point Likert scale (1=" Strongly Disagree" to 5=" Strongly Agree"). All the scales were adopted from prior studies. Top management support assessed using three items adapted from (Li et al., 2015). IT support services measured using three items taken from (Ahmi \& Kent, 2013; Kim et al., 2009). IT committee assessed using three items borrowed from (Ferguson et al., 2013). Audit technology performance assessed using eight items adopted from (Veerankutty et al., 2018).

\section{Results and discussion analysis}

4.1 Respondent demographical information

As shown in Table 1, out of 186 participants, $68.3 \%$ were male, and nearly one-third of them were female. Most of the respondents $43.0 \%$ were aged between 26 and 35 years. Regarding education, most participants $36.5 \%$ had 
a bachelor's degree. Nearly half of the participants had a lower-level job in the organizations. Approximately $39.2 \%$ of participants 2 to 5 years of experience in auditing. Besides, approximately $60.0 \%$ of respondents had less than 2 years of experience in using audit technology.

Table 1. Demographics of participants

\begin{tabular}{|c|c|c|c|}
\hline & & Frequency & Percentage \\
\hline \multirow[t]{2}{*}{ Gender } & Male & 127 & 68.3 \\
\hline & Female & 59 & 31.7 \\
\hline \multirow[t]{4}{*}{ Age (years) } & Less than 25 & 56 & 30.1 \\
\hline & $26-35$ & 80 & 43.0 \\
\hline & $36-45$ & 22 & 11.8 \\
\hline & Over 45 & 28 & 15.1 \\
\hline \multirow[t]{4}{*}{ Education } & Certificate/Diploma & 5 & 2.68 \\
\hline & Bachelor's degree & 68 & 36.5 \\
\hline & Master's degree & 64 & 34.4 \\
\hline & $\begin{array}{llll}\text { Bachelors } & \text { or } & \text { Masters } & + \\
\text { Professional } & & & \\
\end{array}$ & 48 & 25.8 \\
\hline \multirow[t]{3}{*}{ Job position level } & Top management & 43 & 23.1 \\
\hline & Middle management & 55 & 29.6 \\
\hline & Lower management & 88 & 47.3 \\
\hline \multirow[t]{4}{*}{ Experience in auditing } & Less than 2 years & 51 & 27.4 \\
\hline & $2-5$ years & 73 & 39.2 \\
\hline & $6-10$ years & 29 & 15.6 \\
\hline & Above 10 years & 33 & 17.7 \\
\hline \multirow[t]{4}{*}{$\begin{array}{l}\text { Experience in using audit } \\
\text { technology }\end{array}$} & Less than 2 years & 111 & 59.6 \\
\hline & $2-5$ years & 45 & 24.2 \\
\hline & $6-10$ years & 19 & 10.2 \\
\hline & Above 10 years & 11 & 5.9 \\
\hline
\end{tabular}

Furthermore, this study used a two-steps approach to assess both first-order and second-order constructs, which allowed the prediction of a more parsimonious model (Becker et al., 2012). (Hair Joseph et al., 2019) proposed that results analysis of the study using SmartPLS should be reported in the two-step approach (1) Assessment of measurement model and (2) Assessment of structural model

4.2 Assessment of measurement model

According to (Ali Qalati et al., 2021), a proposition to measure the model is required to assess the individual item reliability, internal consistency, content validity, convergent validity, and discriminant validity (refer Table 2).

Individual item reliability was measured by outer loadings of items related to a particular construct (C. Li et al., 2020). (Sikandar Ali QALATI et al., 2020) proposed a value of outer loading should be $\geq 0.7$. According to (W. Li et al., 2020), Cronbach's Alpha (CA), values should exceed 0.7. Internal consistency reliability (Hair Joseph et al., 2019) requires composite reliability (CR) to be $\geq 0.7$. Regarding convergent validity, (Fornell \& Larcker, 1981) recommended that the average variance extracted (AVE) should be $\geq 0.5$. Also, we have evidenced Common method bias (CMB) free-data using the full collinearity approach, i.e., using the variance inflation factor (VIF). The results of the study reflected that CMB is not a concern since the VIF was less than three (Yusheng et al., 2020) (refer to Table 2). 
Table 2. Measurement model

\begin{tabular}{|l|l|c|c|c|c|c|}
\hline Construct & Loadings & Items & CA & CR & AVE & VIF \\
\hline Top management support & TMS1 & 0.937 & 0.926 & 0.953 & 0.871 & 2.638 \\
\hline & TMS2 & 0.928 & & & & \\
\hline & TMS3 & 0.935 & & & & \\
\hline IT support services & ITSS1 & 0.906 & 0.893 & 0.933 & 0.823 & 2.159 \\
\hline & ITSS2 & 0.898 & & & & \\
\hline & ITSS3 & 0.918 & & & & \\
\hline IT committee & ITC1 & 0.934 & 0.927 & 0.953 & 0.872 & 2.794 \\
\hline & ITC2 & 0.937 & & & & \\
\hline Audit technology performance & ITC3 & 0.93 & & & & \\
\hline & ATP1 & 0.833 & 0.932 & 0.945 & 0.709 & \\
\hline & ATP2 & 0.865 & & & & \\
\hline & ATP3 & 0.86 & & & & \\
\hline & ATP4 & 0.799 & & & & \\
\hline & ATP5 & 0.862 & & & & \\
\hline & ATP6 & 0.842 & & & & \\
\hline & ATP7 & 0.832 & & & & \\
\hline
\end{tabular}

Regarding discriminant validity, this study employed Fornell and Larkers's technique and (HTMT) techniques. According to (Fornell \& Larcker, 1981), the square root of the AVE for each construct should exceed the inter-correlations of the construct with other model constructs (refer Table 3). Regarding the HTMT techniques assessment, (Hair Joseph et al., 2019) proposed that the value should be less than 0.85 .

Table 3. Discriminant validity using Heterotrait-Monotrait Ratio (HTMT)

\begin{tabular}{|l|c|c|c|c|}
\hline Constructs & $\begin{array}{c}\text { Audit technology } \\
\text { performance }\end{array}$ & $\begin{array}{c}\text { IT } \\
\text { Committee }\end{array}$ & $\begin{array}{c}\text { IT support } \\
\text { services }\end{array}$ & $\begin{array}{c}\text { Top management } \\
\text { support }\end{array}$ \\
\hline $\begin{array}{l}\text { Audit technology } \\
\text { performance }\end{array}$ & & & & \\
\hline IT Committee & 0.736 & & & \\
\hline IT support services & 0.746 & 0.766 & & \\
\hline $\begin{array}{l}\text { Top management } \\
\text { support }\end{array}$ & 0.83 & 0.82 & 0.742 & \\
\hline
\end{tabular}

\subsection{Assessment of structural model}

This study used PLS bootstrapping with 5000 bootstraps and 186 cases with the motive the examining the hypothesized model and its significance level (Hair Joseph et al., 2019) (refer Table 4). According to (Ahmed, Li, Khan, et al., 2020), the structural model should be used to assess the linear regression effects of the dependent variables on one another. A PLS assessment of the model used path co-efficient, p-value, and coefficients of determination (R2).

Table 4 reveals that the hypotheses of the study were found supported with $(\beta=0.511, p$-value $<0.05)$. This study evidenced that top management support has a positive and statistically significant relationship with audit technology performance. These research findings of the study found consistent with (Ferguson et al., 2013), who evidenced the positive effects of top management support on audit technology performance. The study found the positive IT support services impact on audit technology performance $(\beta=0.251, p$-value $<0.05)$. These findings of the study consistent with (Veerankutty et al., 2018), who argued that IT support services keeping in view the IT governance mechanism has a significant influence on audit technology performance. Furthermore, the study also evidenced a positive but statistically insignificant relationship between IT committee and audit technology performance $(\beta=0.123$, p-value $>0.05)$, therefore hypotheses are not supported. These findings of the study consistent with (Veerankutty et al., 2018).

To evaluate the variance of the constructs, the study used $\mathrm{R}^{2}$ coefficient, which is also called the coefficient of determination (Hair et al., 2011). According to (Cohen, 1998), the value of $\mathrm{R}^{2} 0.60,0.33$, and 0.19 respectively set as a rule of thumb, and these values are described as substantial, moderate, and weak. The value of $\mathrm{R}^{2}$ of this study retained was 0.651 , which implies that $65.1 \%$ variation in the audit technology performance occurred due to workload IT governance (top management support, IT support services, and IT committee). As per (Cohen, 1998) threshold, we stated that this model has a substantial effect (refer to Table 4). We employed the cross-validated redundancy measure $\left(\mathrm{f}^{2}\right)$ and $\left(\mathrm{q}^{2}\right)$ to evaluate the model (Ringle et al., 2012). Values of 0.02, 0.15, and 0.35, respectively, indicate that an exogenous construct has a small, medium, or considerable predictive relevance for a specific endogenous construct (refer to Table 4). 
Table 4. Hypotheses testing

\begin{tabular}{|c|l|c|c|c|c|c|c|c|}
\hline Hypotheses & \multicolumn{1}{|c|}{ Relationships } & $\begin{array}{c}\text { Std. } \\
\text { Beta }\end{array}$ & $\begin{array}{c}\text { Std. } \\
\text { Error }\end{array}$ & $\begin{array}{c}\mathbf{t}- \\
\text { value }\end{array}$ & Decision & $\mathbf{R}^{\mathbf{2}}$ & $\mathbf{f}^{\mathbf{2}}$ & $\mathbf{Q}^{\mathbf{2}}$ \\
\hline H1a & $\begin{array}{l}\text { Top management support } \\
\rightarrow \text { Audit technology } \\
\text { performance }\end{array}$ & 0.51 & 0.079 & 6.46 & Supported & & 0.283 \\
\hline H1b & $\begin{array}{l}\text { IT support services Audit } \\
\rightarrow \text { technology performance }\end{array}$ & 0.25 & 0.067 & 3.723 & Supported & & 0.084 & 0.015 \\
\hline H1c & $\begin{array}{l}\text { IT Committee Audit } \\
\rightarrow \text { technology performance }\end{array}$ & 0.12 & 0.07 & 1.744 & $\begin{array}{c}\text { Not } \\
\text { Supported }\end{array}$ & 0.65 & 0.42 \\
\hline
\end{tabular}

\section{Conclusion}

The distinctiveness of this research lies in the effects of IT governance on audit technology performance; since there were slight studies conducted on the proposed relationship in the context of Ghana, specifically in the public sector. This study evidenced the positive and statistically significant link between proposed constructs. Furthermore, the study witnessed that the IT governance mechanism comprises of top management support, IT support services, and IT committee which is significantly influencing drivers for audit technology performance among Ghanaian public sector auditors employing the PLS-SEM approach in testing hypotheses.

A noteworthy contribution of the study was the utilization of IT governance mechanism affecting the audit technology performance. This is one the limited study which evidenced the and advocates few drivers of the technology, such as IT top management support, support services, and committee into an IT governance construct which is being predicted to energize actions consistent with the firm vision, mission, structure, strategy, and policies (Rau, 2004). Another contribution includes the employment of analytical tool approach PLS-SEM, very few studies have used these techniques in the literature of audit technology performance (Veerankutty et al., 2018). Moreover, this study indicates to practitioners that public sector companies must strengthen IT governance by developing an appropriate IT committee and IT support services for the auditors. In addition, it is critical that firms should elucidate their priorities and requirements associated with technology-based training in their IT policies, and action plans to improve the utilization of audit technology. Furthermore, IT committee should monitor professional standards to ensure adherence to technology-based auditing.

This study has the below-listed limitation,

1. This study is conducted in Ghana and it's all about Ghana.

2. The sample size and methods of data collection were done online and those who don't have internet access were not included in the study.

3. Lastly, associated with the sector, this study involved public sector auditors. Therefore, upcoming studies can include private and public sectors together.

\section{Reference}

Ahmed, N., Li, C., Khan, A., Qalati, S. A., Naz, S., \& Rana, F. (2020). Purchase intention toward organic food among young consumers using theory of planned behavior: role of environmental concerns and environmental awareness. Journal of Environmental Planning and Management, 1-27. https://doi.org/10.1080/09640568.2020.1785404

Ahmed, N., Li, C., Qalati, S. A., Rehman, H. u., Khan, A., \& Rana, F. (2020). Impact of Business Incubators on Sustainable Entrepreneurship Growth with Mediation Effect. Entrepreneurship Research Journal(0), 20190116. https://doi.org/https://doi.org/10.1515/erj-2019-0116

Ahmi, A., \& Kent, S. (2013). The utilisation of generalized audit software (GAS) by external auditors. Managerial Auditing Journal, 28(2), 88-113. https://doi.org/10.1108/02686901311284522

Ali Qalati, S., Li, W., Ahmed, N., Ali Mirani, M., \& Khan, A. (2021). Examining the Factors Affecting SME Performance: The Mediating Role of Social Media Adoption. Sustainability 13(75), 1-25. https://doi.org/https://doi.org/10.3390/su13010075

Alreemy, Z., Chang, V., Walters, R., \& Wills, G. (2016). Critical success factors (CSFs) for information technology governance (ITG). International Journal of Information Management, 36(6, Part A), 907-916. https://doi.org/https://doi.org/10.1016/j.ijinfomgt.2016.05.017

Amid, A., Moalagh, M., \& Zare Ravasan, A. (2012). Identification and classification of ERP critical failure factors in Iranian industries. Information $\quad$ Systems, $\quad 37(3), \quad$ 227-237. https://doi.org/https://doi.org/10.1016/j.is.2011.10.010

Becker, S., Bryman, A., \& Ferguson, H. (2012). Understanding research for social policy and social work: themes, methods and approaches. Policy Press.

Bierstaker, J., Janvrin, D., \& Lowe, D. J. (2014). What factors influence auditors' use of computer-assisted audit 
techniques? in

Accounting,

$30(1)$

$67-74$.

Chege, S. M., \& Wang, D. (2020). The influence of technology innovation on SME performance through environmental sustainability practices in Kenya. Technology in Society, 60, 101210. https://doi.org/https://doi.org/10.1016/j.techsoc.2019.101210

Chege, S. M., Wang, D., \& Suntu, S. L. (2020). Impact of information technology innovation on firm performance in Kenya. Information Technology for Development, 26(2), 316-345. https://doi.org/10.1080/02681102.2019.1573717

Christensen, B. (2016). Arriving at Internal Audit's Tipping Point Amid Business Transformation. EDPACS, 54(1), 15-16. https://doi.org/10.1080/07366981.2016.1195674

Cohen, J. (1998). Statistical Power Analysis for the Behavioural Sciences, xxi. Hillsdale, NJ: L Erlbaum associates.

Ferguson, C., Green, P., Vaswani, R., \& Wu, G. (2013). Determinants of Effective Information Technology Governance [https://doi.org/10.1111/j.1099-1123.2012.00458.x]. International Journal of Auditing, 17(1), 75-99. https://doi.org/https://doi.org/10.1111/j.1099-1123.2012.00458.x

Fornell, C., \& Larcker, D. F. (1981). Evaluating structural equation models with unobservable variables and measurement error. Journal of marketing research, 18(1), 39-50.

Hair, J. F., Ringle, C. M., \& Sarstedt, M. (2011). PLS-SEM: Indeed a silver bullet. Journal of Marketing theory and Practice, 19(2), 139-152.

Hair Joseph, F., Risher Jeffrey, J., Sarstedt, M., \& Ringle Christian, M. (2019). When to use and how to report the results of PLS-SEM. European Business Review, 31(1), 2-24. https://doi.org/10.1108/EBR-11-2018-0203

Ibrahim, M., Bawole Justice, N., Obuobisa-Darko, T., Abubakar, A.-B., \& Kumasey Anthony, S. (2017). The legal regime and the compliance façade in public procurement in Ghana. International Journal of Public Sector Management, 30(4), 370-390. https://doi.org/10.1108/IJPSM-09-2016-0156

Joshi, A., Bollen, L., Hassink, H., De Haes, S., \& Van Grembergen, W. (2018). Explaining IT governance disclosure through the constructs of IT governance maturity and IT strategic role. Information \& Management, 55(3), 368-380. https://doi.org/https://doi.org/10.1016/j.im.2017.09.003

KAHYAOĞLU, S. B., Sarikaya, R., \& TOPAL, B. (2020). Continuous Auditing as a Strategic Tool in Public Sector Internal Audit: The Turkish Case. Selçuk Üniversitesi Sosyal Bilimler Meslek Yüksekokulu Dergisi, 23(1), 208-225.

Kim, H.-J., Mannino, M., \& Nieschwietz, R. J. (2009). Information technology acceptance in the internal audit profession: Impact of technology features and complexity. International Journal of Accounting Information Systems, 10(4), 214-228. https://doi.org/https://doi.org/10.1016/j.accinf.2009.09.001

Li, C., Ahmed, N., Sikandar Ali, Q., Khan, A., \& Naz, S. (2020). Role of Business Incubators as a Tool for Entrepreneurship Development: The Mediating and Moderating Role of Business Start-up and Government Regulations. Sustainability, 12(5), 1822. https://doi.org/https://doi.org/10.3390/su12051822

Li, W., Qalati, S. A., Khan, M. A. S., Kwabena, G. Y., Erusalkina, D., \& Anwar, F. (2020). Value Co-creation and Growth of Social Enterprises in Developing Countries: Moderating Role of Environmental Dynamics. Entrepreneurship Research Journal(0), 20190359. https://doi.org/https://doi.org/10.1515/erj-2019-0359

Li, X., Pillutla, S., Zhou, H., \& Yao, D.-Q. (2015). Drivers of Adoption and Continued Use of E-Procurement Systems: Empirical Evidence from China. Journal of Organizational Computing and Electronic Commerce, 25(3), 262-288. https://doi.org/10.1080/10919392.2015.1058113

Lunardi, G. L., Maçada, A. C. G., Becker, J. L., \& Van Grembergen, W. (2017). Antecedents of IT governance effectiveness: An empirical examination in Brazilian firms. Journal of Information Systems, 31(1), 41-57.

Mahzan, N., \& Lymer, A. (2014). Examining the adoption of computer-assisted audit tools and techniques: Cases of generalized audit software use by internal auditors. Managerial Auditing Journal, 29(4), 327-349. https://doi.org/10.1108/MAJ-05-2013-0877

Mehdi, K., Ismael Bouassida, R., Youssef Ben, H., \& Samir, M. (2018). IT Governance in Higher Education Institutions: A Systematic Literature Review. International Journal of Human Capital and Information Technology Professionals (IJHCITP), 9(2), 52-67. https://doi.org/10.4018/IJHCITP.2018040104

Mikalef, P., Pateli, A., \& van de Wetering, R. (2020). IT architecture flexibility and IT governance decentralisation as drivers of IT-enabled dynamic capabilities and competitive performance: The moderating effect of the external environment. European Journal of Information Systems, 1-29. https://doi.org/10.1080/0960085X.2020.1808541

Miklos, A. V., \& Romero, S. (2014). Technology in audit engagements: a case study. Managerial Auditing Journal, 29(4), 350-365. https://doi.org/10.1108/MAJ-06-2013-0881

Mukhtar, R., \& Ali, N. A. (2011). Quality governance of human aspects of quality initiatives in the public service sector. Current Issues of Business \& Law, 6(1).

Nfuka Edephonce, N., \& Rusu, L. (2011). The effect of critical success factors on IT governance performance. Industrial Management \& Data Systems, 111(9), 1418-1448. https://doi.org/10.1108/02635571111182773 
Qalati, S. A., Ahmed, N., Mei, J., Thu, T. T. H., \& Sohu, J. M. (2020). Stay Home Stay Safe: General Public Knowledge, Attitude and Behavior Regarding Covid-19 During the Lockdown in Developing Countries. International Journal of Humanities, Arts and Social Sciences, 6(2), 69-77. https://doi.org/https://dx.doi.org/10.20469/ijhss.6.20002-2

Qalati, S. A., Li, W., Mirani, S. H., Sohu, J. M., Hussain, R. Y., \& Ahmed, N. (2020). The Antecedents of Green Consumer Behavior the Mediating Role of Brand Image in the Cosmetic Industry. Sukkur IBA Journal of Management and Business, 7(1), 19-39.

Qalati, S. A., Wenyuan, L., Kawabena, G., Erusalkina, D., \& Pervaiz, S. (2019). Influence of Brand Equity on Brand Performance: Role of Brand Reputation and Social Media. International Journal of Research and Review, 6(9), 304-317.

QALATI, S. A., Wenyuan, L., VELA, E. G., Ali, B., BARBOSA, B., \& HERZALLAH, A. M. (2020). Effects of technological, organizational, and environmental factors on social media adoption. The Journal of Asian Finance, Economics and Business (JAFEB), 7(10), 989-998.

Qiang, M., Kwabena, G.-Y., Wenyuan, L., Ali Qalati, S., \& Erusalkina, D. (2019). Hedonic and Utilitarian Orientation towards the Purchase Intention of Laptop; the Mediating Effect of Information Quality. An Empirical Study of Ghana. International Journal of Management (IJM), 10(6).

Rau, K. G. (2004). Effective Governance of It: Design Objectives, Roles, and Relationships. Information Systems Management, 21(4), 35-42. https://doi.org/10.1201/1078/44705.21.4.20040901/84185.4

Ringle, C. M., Sarstedt, M., \& Straub, D. (2012). A critical look at the use of PLS-SEM in MIS Quarterly. MIS Quarterly (MISQ), 36(1).

Saunders, M., Lewis, P., \& Thornhill, A. (2009). Research methods for business students. Pearson education.

Shiraz Rahaman, A. (2009). Independent financial auditing and the crusade against government sector financial mismanagement in Ghana. Qualitative Research in Accounting \& Management, 6(4), 224-246. https://doi.org/10.1108/11766090910989509

Siew, E.-G., Rosli, K., \& Yeow, P. H. P. (2020). Organizational and environmental influences in the adoption of computer-assisted audit tools and techniques (CAATTs) by audit firms in Malaysia. International Journal of Accounting Information Systems, 36, 100445. https://doi.org/https://doi.org/10.1016/j.accinf.2019.100445

Sikandar Ali, Q., Wenyuan, L. I., Esthela Galvan, V., Ali, B. U. X., Belem, B., \& Ahmed Muhammad, H. (2020). Effects of Technological, Organizational, and Environmental Factors on Social Media Adoption. The Journal of Asian Finance, Economics and Business, 7(10), 989-998.

Sirisomboonsuk, P., Gu, V. C., Cao, R. Q., \& Burns, J. R. (2018). Relationships between project governance and information technology governance and their impact on project performance. International Journal of Project Management, 36(2), 287-300. https://doi.org/https://doi.org/10.1016/j.ijproman.2017.10.003

Smidt, L., Ahmi, A., Steenkamp, L., van der Nest, D. P., \& Lubbe, D. (2019). A Maturity-level Assessment of Generalised Audit Software: Internal Audit Functions in Australia [https://doi.org/10.1111/auar.12252]. Australian Accounting Review, 29(3), 516-531. https://doi.org/https://doi.org/10.1111/auar.12252

Tarek, M., Mohamed Ehab, K. A., Hussain Mostaq, M., \& Basuony Mohamed, A. K. (2017). The implication of information technology on the audit profession in developing country: Extent of use and perceived importance. International Journal of Accounting \& Information Management, 25(2), 237-255. https://doi.org/10.1108/IJAIM-03-2016-0022

Telino, V., Massa, R., Mota, I., Gomes, A., \& Moreira, F. (2020). A Methodology for Creating a Macro Action Plan to Improve IT Use and Its Governance in Organizations. Information, 11(9), 427.

Tian, H., Iqbal, S., Akhtar, S., Qalati, S. A., Anwar, F., \& Khan, M. A. S. (2020). The Impact of Transformational Leadership on Employee Retention: Mediation and Moderation Through Organizational Citizenship Behavior and Communication [Original Research]. Frontiers in Psychology, 11(314). https://doi.org/10.3389/fpsyg.2020.00314

Veerankutty, F., Ramayah, T., \& Ali, N. A. (2018). Information technology governance on audit technology performance among Malaysian public sector auditors. Social Sciences, 7(8), 124. https://doi.org/10.3390/socsci7080124

World Bank. (2016). Project Performance Assessment Report of the Republic of Ghana eGhana Project. Independent Evaluation Group Washington, DC.

Xu, L. D. (2020). The contribution of systems science to Industry 4.0 [https://doi.org/10.1002/sres.2705]. Systems Research and Behavioral Science, 37(4), 618-631. https://doi.org/https://doi.org/10.1002/sres.2705

Yusheng, K., Jonathan Dior, N. N., \& Sikandar Ali, Q. (2020). Effects of Financial Rewards, Parents and Peers, and Benefits and Costs on Choosing Accounting Career: A Global Perspective. The Journal of Asian Finance, Economics and Business, 7(11), 157-167. 